\title{
Effects of feeding zooplankton, Moina macrocopa (Straus, 1820) on the growth of Nile tilapia Oreochromis niloticus L.
}

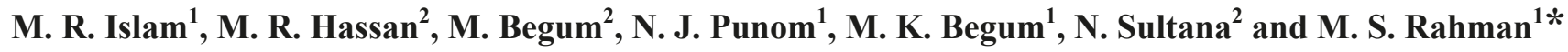 \\ ${ }^{I}$ Department of Fisheries, Faculty of Biological Sciences, University of Dhaka, Dhaka-1000, Bangladesh \\ ${ }^{2}$ Zoology Section, Biological Research Division, Bangladesh Council of Scientific and Industrial Research (BCSIR), Dhaka \\ 1000, Bangladesh
}

\begin{abstract}
Studies were carried out on the growth performance of Tilapia fry, Oreochromis niloticus cultured with zooplankton, Moina macrocopa in comparison to commercial feed. Three types of feed were used in three treatments where treatment-1 was fed with handmade feed (control), treatment-2 with commercial feed and treatment-3 with live zooplankton $M$. macrocopa. Thirty fry were stocked in each $60 \mathrm{~L}$ aquarium for a rearing period of 56 days. The fishes were fed twice a day at 90-400 Moina/individual fish for first 20 days, then 500-850 Moina/individual fish for 15 days and 900-1250 Moina/individual fish for remaining days. Sampling was done at 14 days interval. The growth performance of M. macrocopa was higher in the treatment fed with Spirulina which was 6350 individuals/ L of water and in the treatment fed with yeast it was 5100 individuals/L of water at $12^{\text {th }}$ days. The study showed that condition factor of tilapia fry found in treatment-3 fed with $M$. macrocopa was comparatively higher (2.18 \pm 0.09$)$ than that of treatment- 2 fed with commercial feed $(1.86 \pm 0.13)$ at a 56-day culture period. Average daily gain was significantly higher in the treatment- 3 fed with $M$. macrocopa $(0.13 \pm 0.01)$ than those of treatment- $1(0.06 \pm 0.01)$ and treatment-2 $(0.08 \pm 0.01)$. The best value of feed conversion ratio and specific growth rate was found in treatment- 3 fed with M. macrocopa than commercial feed and handmade feed. Protein content was significantly higher (15.91\%) in treatment-3 than those of treatment-1 (10.96\%) and treatment-2 $(11.88 \%)$. The findings of this study suggest that growth parameters and body composition of Nile Tilapia was better in treatment-3 fed with M. macrocopa.
\end{abstract}

Keywords: Moina macrocopa; Nile tilapia Oreochromis niloticus; Live food; Growth performance; Body composition

\section{Introduction}

In many tropical and subtropical areas of Africa, America and Asia, Tilapia is as an important food fish item. Throughout the world it serves a new scenario on aquaculture as an extensive source of animal protein and income (Barriga-Sosa et al., 2004). Like some Asian countries, Bangladesh introduces Nile Tilapia, Oreochromis niloticus in 1974. Zooplanktons are important food components for young and some adult freshwater fishes (Kenneth, 1990). Throughout the year, among freshwater zooplankton, rotifers, cladocerans and copepods are dominant group (Hutchinson, 1967). For certain qualities such as purity, availability, acceptance, nutritional indicators, digestibility, reproductive and economic viability, some zooplanktons are selected as food sources in fish larvae culture (Watanabe and Kiron, 1994). Sufficient dietary supply of protein is needed for optimum growth of fish thus protein is the main constituents of the fish body.
Freshwater cladoceran or water flea Moina macrocopa has an excellent potential as a live food for larvae of finfish and crustaceans (Alam et al., 1993; Kang et al., 2006). Moina contains superior nutritional value than commercially available newly hatched Artemia nauplii (He et al., 2001). Worldwide distribution of Moina has increasing demand for food of larvae and juvenile finfish, because of their rapid growth potential (Pennak, 1989; Benider et al., 1998). The protein content of Moina usually averages $50 \%$ of the dry weight and the total amount of fat per dry weight is $20-27 \%$ for adult females and 4-6\% for juveniles (Rottmann et al., 2003). All zooplanktons are not suitable for fry rearing but live rotifers, Moina and Daphnia species are reported to be good freshwater zooplanktons that can enhance protein and other nutritional values of farmed fish (Olojo et al., 2003). Larger prey such as Moina, Daphnia become preferable with the increasing age and size of fish larvae, most of early fish larvae consume rotifers in large amount (Khadka and Rao, 1986).

\footnotetext{
* Corresponding author e-mail: shamsur@du.ac.bd
} 
Cladocerans have been found to be rich in essential nutrients, are easily ingested and digested by fish larvae, fulfill the larval dietary requirements and improve water quality by minimizing the need for artificial feeding (He et al., 2001).

Various kinds of live food or zooplankton can be used as diets for fish fry and; the culture and utilization of these potential organisms are vital for fish fry production in hatcheries. Information about mass culture and nutritional values of $M$. macrocopa under suitable culture conditions and its applications as live food for freshwater Tilapia culture improves the quality, quantity and cost effectiveness of the production facilities. The present study was aimed at rearing M. macrocopa and to investigate the growth and body composition of Tilapia fry fed with $M$. macrocopa as live zooplankton feed.

\section{Materials and methods}

Experimental design

The whole experiment was designed for 2 types of culture; a) culture of live zooplankton $M$. macrocopa and b) culture of experimental fish fry of Tilapia, O. niloticus.

Experiment 1: Effects of different diets on rearing $M$. macrocopa

The experimental organism, M. macrocopa samples were collected from various places of Gulshan Lake (about $23^{\circ} 48^{\prime}$ $\mathrm{N}$ latitude and $90^{\circ} 25^{\prime} \mathrm{E}$ longitude), the northernmost lake in a chain of water bodies located in Dhaka city and carried to the laboratory located in Zoology Section, Biological Research Division, Bangladesh council of Scientific and Industrial Research (BCSIR). Samples of M. macrocopa were easily collected in winter (November) from the water surface by sieve number 270 (mesh=0.05 $\mathrm{mm}$ ) and kept in cool and dry place. The collected $M$. macrocopa was identified according to Brooks (1959). To prepare M. macrocopa stocks, collected samples were kept in aquarium at a temperature of $25 \pm 2{ }^{\circ} \mathrm{C}$ and having $\mathrm{pH}$ of 7.5 and aerated vigorously. After 7 days, aeration was stopped and they were removed to some new aquaria by siphoning out. Before starting the main experiment, they were fed with Spirulina flake. During stock maintenance, culture was examined daily, all exuviae and any dead individuals were removed and up to $50 \%$ of water was also changed twice a week.

M. macrocopa was semi continuously cultured for 30 days. The culture was designed as four treatments and each treatment had two replications. Treatment-1 was fed with handmade feed, treatment- 2 was fed with cabbage leaves, treatment-3 was fed with yeast and treatment-4 was fed with Spirulina (Spirulina platensis) flake.
Mass cultivation of $M$. macrocopa was carried out in eight aquariums of size $0.9 \mathrm{~m} \times 0.46 \mathrm{~m} \times 0.6 \mathrm{~m}$ with 24 hours aeration having 60 liters of tap water under natural light illumination at a temperature of $25 \pm 2{ }^{\circ} \mathrm{C}$ adjusted by using thermostatically controlled heaters, $\mathrm{pH} 7 \pm 1$ and a dissolved oxygen level of 3-6 mg/L. The tap water was left one day for seasoning. On the 2 nd day feed was applied in the aquarium according to the experimental design. On the 3rd day, 200 individual of M. macrocopa was stocked to each aquarium. To count the population of zooplankton $1000 \mathrm{ml}$ of culture water was sampled randomly and then in $1 \mathrm{ml}$ of that water was taken by a dropper and number of zooplankton was counted. Finally total population density was determined according to the formula outlined by Ovie (1991): $\mathrm{P}_{\mathrm{d}}=$ $100 \times \mathrm{B}_{\mathrm{x}} / \mathrm{V} \mathrm{ml}$, where $\mathrm{P}_{\mathrm{d}}=$ population density of $\mathrm{M}$. macrocopa in $1000 \mathrm{ml}$ of water, $\mathrm{V}=$ Average volume of water sample, $\mathrm{B}_{\mathrm{x}}=$ Average number of $M$. macrocopa counted in various random sampling.

Experiment 2: Effects of M. macrocopa on culture of Tilapia fry

The culture of $O$. niloticus was conducted for 56 days. The experiment was designed as three treatments where treatment-1 was fed with handmade feed (control), treatment- 2 was fed with commercial feed \& treatment-3 was fed with live food $M$. macrocopa (fed Spirulina). The proximate composition of the experimental diets are shown in Table I. The experimental homemade feed was combined with fish grain $13.7 \%$, shrimp grain $13.7 \%$, soybean $13.7 \%$, Wheat $14.5 \%$, vitamin and minerals $0.85 \%$, corn grain $14.5 \%$, rice bran $14.5 \%$, oil cake $13.7 \%$ and fat $0.85 \%$. Six culture aquariums of $1.1 \mathrm{~m} \times 0.46 \mathrm{~m} \times 0.3 \mathrm{~m}$ were washed, drained and left to dry for a couple of day prior to the beginning of the experiment. The experimental aquariums were disinfected by $70 \%$ alcohol prior to the experiment started.

Fry of Tilapia (O. niloticus) $(2.87 \pm 0.04 \mathrm{~cm}$ and $0.424 \pm 0.03$ $\mathrm{g}$ ) were collected from Mymensingh and carried in oxygenated bags with water in the laboratory located in Zoology Section, BCSIR Lab, Dhaka. Before stocking, Tilapia fry were acclimated in laboratory conditions at a temperature of $25 \pm 2^{\circ} \mathrm{C}$ adjusted by using thermostatically controlled heaters, $\mathrm{pH} 7 \pm 1,24 \mathrm{~h}$ continuous aeration and a dissolved oxygen level of 3-6 mg/L for $24 \mathrm{~h}$ without supplying any food.

The fry were randomly distributed at a rate of 30 fry per aquarium. The three diets were fed to the experimental fish in six replicate aquariums per dietary treatment. Feeding was done twice daily at 90-400 Moina/individual fish for first 20 days, then 500-850 Moina/individual fish for 15 days and 900-1250 Moina/individual fish for remaining days. Each 
ration was divided into two equal parts, one portion was offered at $10.00 \mathrm{am}$ while the other at $5.00 \mathrm{pm}$. Partial exchange of water from each aquarium was done daily during the removal of uneaten feed and faeces. Physico-chemical parameters of water such as temperature, dissolve oxygen, $\mathrm{pH}$, conductivity, total dissolve substance and light intensity were recorded twice in a week.

Sampling was performed in the $14^{\text {th }}, 28^{\text {th }}, 42^{\text {th }}$ and $56^{\text {th }}$ day of the experimental period and, length and weight of individual fish were recorded for further analyses.

\section{Growth indices}

Fish growth performance was calculated using the following formulae:

a) Condition factor, $\mathrm{K}=\mathrm{W} / \mathrm{L}^{3} \times 100$ Where, $\mathrm{K}=$ Condition factor, $\mathrm{W}=$ Body weight in grams and $\mathrm{L}=$ Body length in centimeters

b) Average Daily Gain (ADG, g/day) $=($ Mean final weight mean initial weight) /time interval (days)

c) Specific Growth Rate $(\%$ day $)=\left(\log _{\mathrm{e}}\right.$ final weight $-\log _{\mathrm{e}}$ initial weight) $/$ time interval (days) $\times 100$

d) Feed Conversion Ratio $($ FCR $)=$ Feed consumed by the fish / weight gain by the fish

e) Survival Rate $(\%)=$ Number of fry that survived $/$ Total no. of fry stocked $\times 100$

\section{Body composition analysis}

At the end of the 56-day rearing period of Tilapia fry total protein (micro-Kjeldahl method), total lipid, ash and moisture content were determined (AOAC, 1995). Moisture content was estimated by drying the samples to constant weight at $105^{\circ} \mathrm{C}$ in a drying oven and nitrogen content using a micro-Kjeldahl apparatus (Automatic Kjeldahl Digester, DKL 8 Series, VELP Scientifica, Italy and Kjeltec 2100, Distillation Unit, FOSS Analytical, Denmark). Crude protein was estimated by multiplying nitrogen content by 6.25 . Lipid content was determined by ether extraction in a multi-unit Soxhlet extraction apparatus for $16 \mathrm{~h}$. Ash was determined by combusting dry samples in a Muffle Furnace at $550^{\circ} \mathrm{C}$ for $6 \mathrm{~h}$

\section{Statistical analysis}

Data were analyzed by using one-way ANOVA followed by Tukey's HSD post hoc for multiple comparisons. The data were presented as mean \pm SEM and evaluated by using the statistical package of SPSS (version 20.0) with the level of significance at $\mathrm{p}<0.05$.

\section{Results and discussion}

The present study described the effect of different diets on the population of zooplankton, $M$. macrocopa at different rearing periods and the effect of $M$. macrocopa on the growth parameters and body composition (moisture, protein, fat and ash) of Nile Tilapia fry.

\section{Water quality parameters}

Water temperature, dissolved oxygen and $\mathrm{pH}$ for the culture of $M$. macrocopa are given in Table I. In the present study the temperature for culturing $M$. macrocopa was $27.99 \pm 1.03^{\circ} \mathrm{C}$. In the culture period of $M$. macrocopa the $\mathrm{pH}$ of water was $8.09 \pm 0.18$ having dissolved oxygen of $5.74 \pm 0.22 \mathrm{mg} / \mathrm{L}$.

In the present study for rearing Tilapia fry dissolved oxygen, temperature, $\mathrm{pH}$, conductivity, total dissolved substance and light intensity were found $5.61 \pm 0.13 \mathrm{mg} / \mathrm{L}, 25.82 \pm 0.91{ }^{\circ} \mathrm{C}$, $8.01 \pm 0.09,7.03 \pm 0.04 \mu \mathrm{s} / \mathrm{cm}, 4.41 \pm 0.03 \mathrm{mg} / \mathrm{L}, 0.3 \pm 0.1$ $1 \mathrm{x}$, in different feeding trial of Nile Tilapia, respectively (Table II).

Water quality parameter for culturing of M. macrocopa and $O$. niloticus in this experiment varied with the type of diet supplied without affecting the growth of the fish. No significant difference was found in temperature, $\mathrm{pH}$ and dissolved oxygen. Rottmann et al. (2003) showed that the optimum temperature for culturing Moina ranges from $24-31^{\circ} \mathrm{C}$ and low temperatures reduced its production. They also suggested that excessively high $\mathrm{pH}(>9.5)$ may inhibit the production of Moina adjusting the culture water $\mathrm{pH}$ to 7-8.

Experiment 1: Effects of different diets and rearing period on population density of M. macrocopa

The results of the rearing period of growth of M. macrocopa indicated that population density was increased from day 3 to the day 13 in all treatments except handmade feed (Fig. 1). Among four treatments, population of $M$. macrocopa was increased from 20 individual/L of water to 6350 individuals/L of water in the $13^{\text {th }}$ day in treatment- 4 fed with Spirulina. The declining growth rate of $M$. macrocopa was observed from the $14^{\text {th }}$ to $24^{\text {th }}$ day in treatment- 4 fed with Spirulina. After that, the growth rate was increased. In the treatment fed with yeast, population of M. macrocopa was enhanced from 10 individuals/ $\mathrm{L}$ of water to 5100 individuals/ $\mathrm{L}$ of water in the $13^{\text {th }}$ day during growth period. Then declining growth rate was observed from the $14^{\text {th }}$ to $21^{\text {th }}$ day. After that the increasing growth rate was recorded. In handmade feed treatment, after 9 days no individual was found in the random sample water. In cabbage leaves, maximum growth was found in the $13^{\text {th }}$ day which was 1900 individuals/L of water. Then population was gradually declined up to 27 days. On the other hand, rearing period of 
Table I. Water quality parameters in live zooplankton feed, M. macrocopa culture aquarium under different treatments during the study period

\begin{tabular}{lcccc}
\hline Parameter & \multicolumn{3}{c}{ Diet type } \\
\cline { 2 - 5 } & Cabbage leaf & Handmade feed & Yeast & Spirulina \\
\hline Temperature $\left({ }^{\circ} \mathrm{C}\right)$ & $28.2 \pm 1.02$ & $28.2 \pm 1.15$ & $28.08 \pm 1.21$ & $27.48 \pm 0.73$ \\
Dissolved oxygen $(\mathrm{mg} / \mathrm{L})$ & $5.57 \pm 0.31$ & $5.39 \pm 0.30$ & $6.06 \pm 0.14$ & $5.94 \pm 0.12$ \\
$\mathrm{pH}$ & $7.9 \pm 0.06$ & $8.28 \pm 0.30$ & $8.26 \pm 0.29$ & $7.94 \pm 0.07$ \\
Conductivity $(\mu \mathrm{s} / \mathrm{cm})$ & $6.99 \pm 0.06$ & $6.91 \pm 0.08$ & $6.87 \pm 0.06$ & $6.95 \pm 0.06$ \\
TDS $(\mathrm{mg} / \mathrm{L})$ & $4.95 \pm 0.30$ & $6.02 \pm 0.08$ & $6.14 \pm 0.21$ & $6.09 \pm 0.09$ \\
Light intensity $(\mathrm{lx})$ & $3.06 \pm 2.40$ & $2.40 \pm 1.89$ & $2.42 \pm 1.89$ & $2.64 \pm 0.96$ \\
\hline
\end{tabular}

Table II. Water quality parameters in Nile Tilapia, $O$. niloticus aquarium under different treatments during the study period

\begin{tabular}{lccc}
\hline Parameter & \multicolumn{3}{c}{ Diet type } \\
\cline { 2 - 4 } & $\begin{array}{c}\text { Handmade feed } \\
(\text { Control })\end{array}$ & $\begin{array}{c}\text { Commercial feed } \\
\text { Live feed ( M. } \\
\text { macrocopa })\end{array}$ \\
\hline Temperature $\left({ }^{\circ} \mathrm{C}\right)$ & $25.92 \pm 0.94$ & $25.82 \pm 0.91$ & $25.76 \pm 0.81$ \\
Dissolved oxygen $(\mathrm{mg} / \mathrm{L})$ & $5.53 \pm 0.28$ & $5.57 \pm 0.27$ & $5.61 \pm 0.13$ \\
$\mathrm{pH}$ & $8.16 \pm 0.28$ & $8.05 \pm 0.17$ & $8.01 \pm 0.09$ \\
Conductivity $(\mu \mathrm{s} / \mathrm{cm})$ & $7.04 \pm 0.08$ & $7.00 \pm 0.10$ & $7.03 \pm 0.04$ \\
TDS $(\mathrm{mg} / \mathrm{L})$ & $4.35 \pm 0.07$ & $4.42 \pm 0.08$ & $4.41 \pm 0.03$ \\
Light intensity $(\mathrm{lx})$ & $0.39 \pm 0.10$ & $0.39 \pm 0.10$ & $0.4 \pm 0.05$ \\
\hline
\end{tabular}

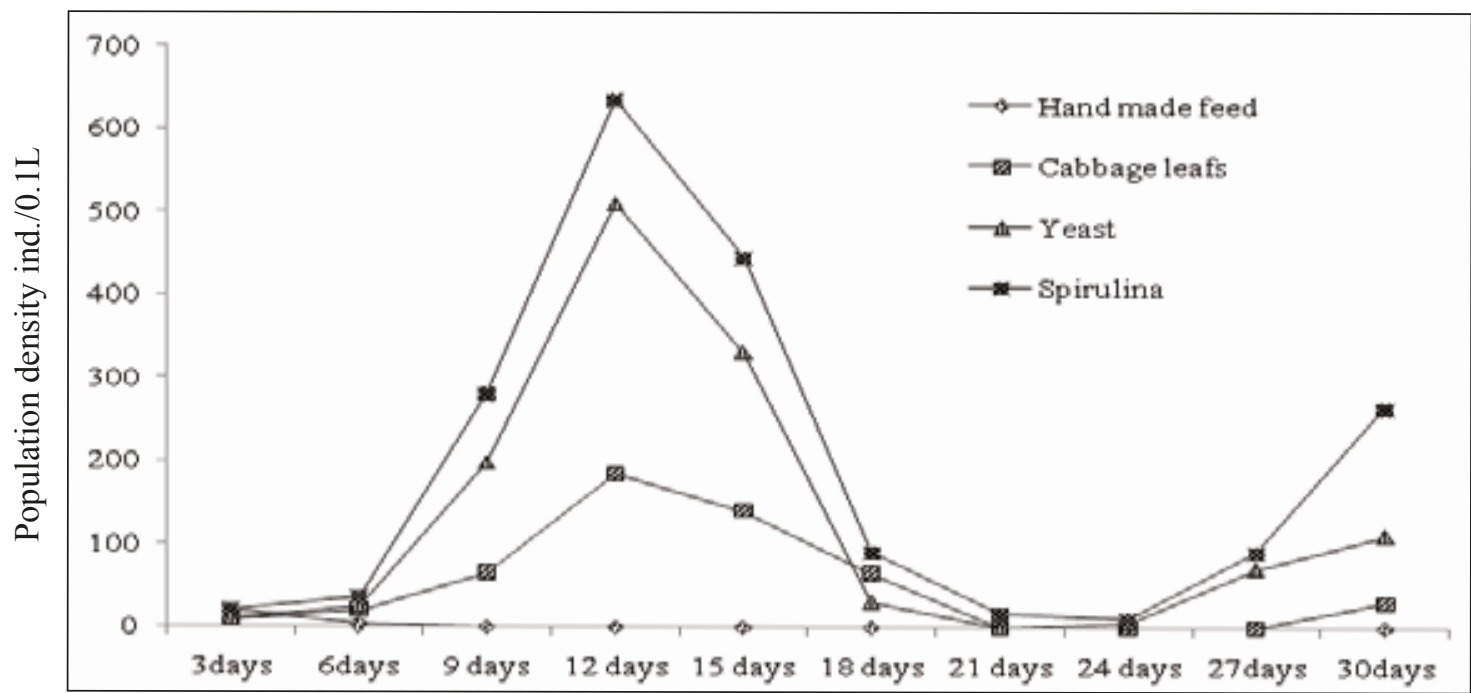

Fig. 1. Effects of rearing period on the number of individuals of $M$. macrocopa in four types of feed media

M. macrocopa with 4 different feed media, Spirulina showed the highest population density.

In the culture of live zooplankton feed, M. macrocopa highest population density was detected in the treatment fed with Spirulina at the $13^{\text {th }}$ day. According to Rottmann (2003) Moina reproduces at only 4-7 days of age, with a brood size of 4-22 per female. Broods are produced every 1.5-2.0 days, 
with most females producing 2-6 broods during their lifetime. The growth, reproductive potentials and longevity of Moina sp. are affected by the nutrient conditions of the culture media (Jana and Chakrabarti, 1993). Loh et al. (2009) reported that $M$. macrocopa fed with Spirulina elapsed 7 days for rising population to its peak.

\section{Experiment 2: Effects of M. macrocopa on culture of Tilapia fry}

Growth performances of $O$. niloticus fed with $M$. macrocopa Higher growth and feed utilization of Tilapia fry were observed in the present study having $M$. macrocopa as live feed. This study revealed that growth indices such as condition factor, ADG, FCR, survival rate and SGR of Nile Tilapia were better for live feed, M. macrocopa than those of other feed.

Condition factor: The highest condition factor was found in the treatment-3 $(2.18 \pm 0.09)$ fed with live feed and the lowest was in the treatment-1 $(1.87 \pm 0.09)$ fed with handmade feed given in Fig. 2. On the $56^{\text {th }}$ day, comparatively higher value $(2.18 \pm 0.09)$ was found in live feed treatment than those of handmade and commercial feed.

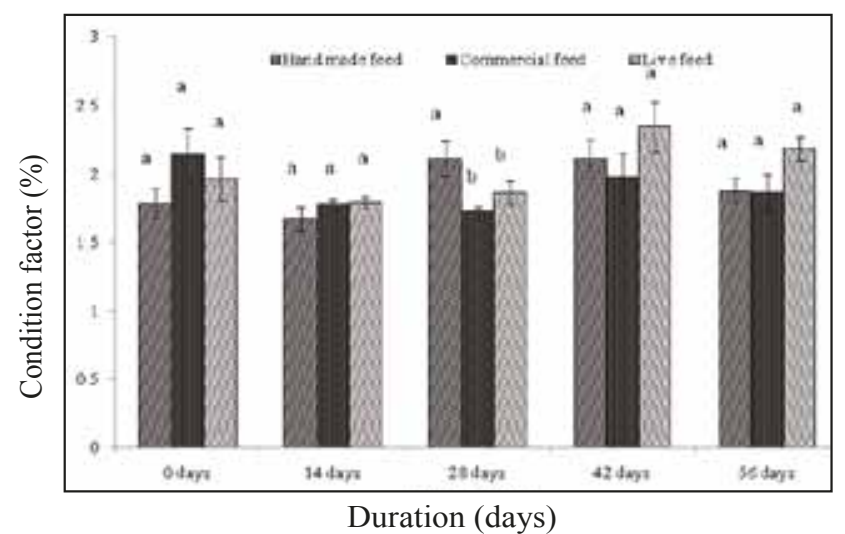

Fig. 2. Condition factor (\%) of Tilapia fry at 56 days rearing period. Bars (Mean \pm SEM) with different letters are significantly different within group (ANOVA, HSD; p $<0.05$ )

Average daily gain (ADG g/day): Fig. 3 represented the highest average daily gain of Tilapia fry was found in treatment- 3 and the lowest was in treatment-1. The ADG value of treatment-3 $(0.13 \pm 0.01)$ was significantly higher than that of treatment-1 $(0.06 \pm 0.01)$ at $5 \%$ level. On the $14^{\text {th }}$ and $28^{\text {th }}$ days average daily gain of fish fed with live feed was found highly significant compared to handmade and commercial feed. On the $56^{\text {th }}$ day, significantly (ANOVA, $\mathrm{F}_{2,29}=5.995, \mathrm{p}<0.05$ ) higher average daily gain was observed in live feed treatment $(0.13 \mathrm{~g} /$ day $)$ compared to commercial feed $(0.08 \mathrm{~g} /$ day $)$.

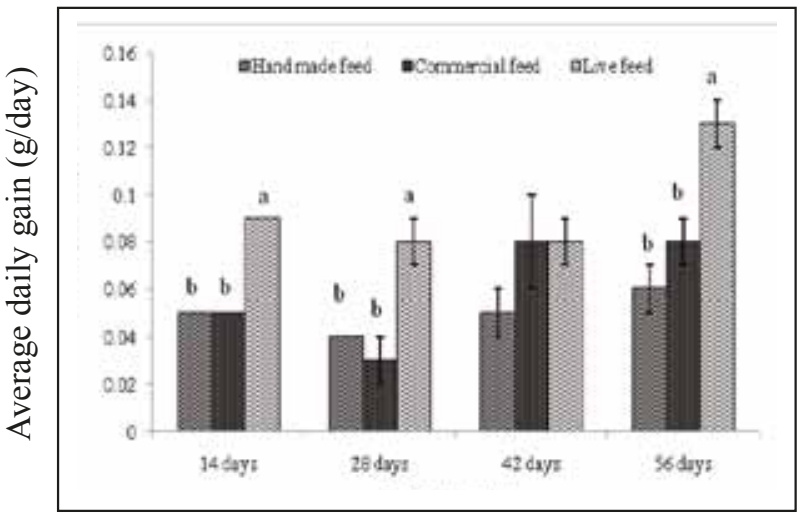

Duration (days)

Fig. 3. Average daily gain (g/day) of Tilapia fry at 56 days rearing period. Bars (Mean \pm SEM) with different letters are significantly different within group (ANOVA, HSD; p<0.05)

Feed conversion ratio ( $F C R)$ : Fish, that were fed on live feed $(1.74 \pm 0.17)$ exhibited lowest feed conversion ratio (FCR) than those fed on handmade $(3.14 \pm 0.72)$ and commercial feed $(2.23 \pm 0.54)$. On the $56^{\text {th }}$ day, feed conversion ratio did not differ significantly (ANOVA, $\mathrm{F}_{2}$, $\left.{ }_{29}=0.833, \mathrm{p}>0.05\right)($ Fig. 4)

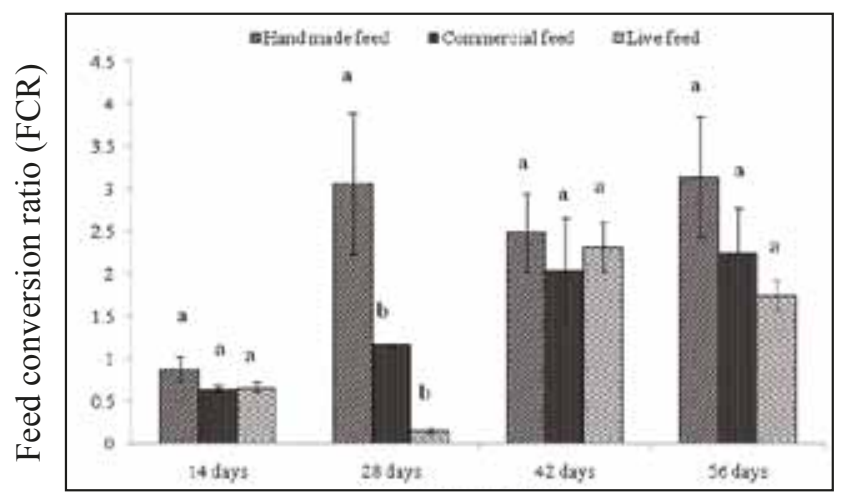

Duration (days)

Fig. 4. Feed conversion ratio of Tilapia fry at 56 days rearing period. Bars (Mean \pm SEM) with different letters are significantly different within group (ANOVA, HSD; $\mathbf{p}<\mathbf{0 . 0 5 )}$

Specific growth rate (\%): The highest specific growth rate of Tilapia fry was found in treatment-3 $(2.58 \pm 0.20 \%)$ and the lowest was in treatment-1 $(2.18 \pm 0.44 \%)$. SGR value of treatment- 2 was higher than treatment-1 and lower than treatment-3 (Fig. 5). On the $56^{\text {th }}$ day specific growth rate did not vary significantly (ANOVA, $\mathrm{F}_{2,29}=0.981, \mathrm{p}>0.05$ ). 


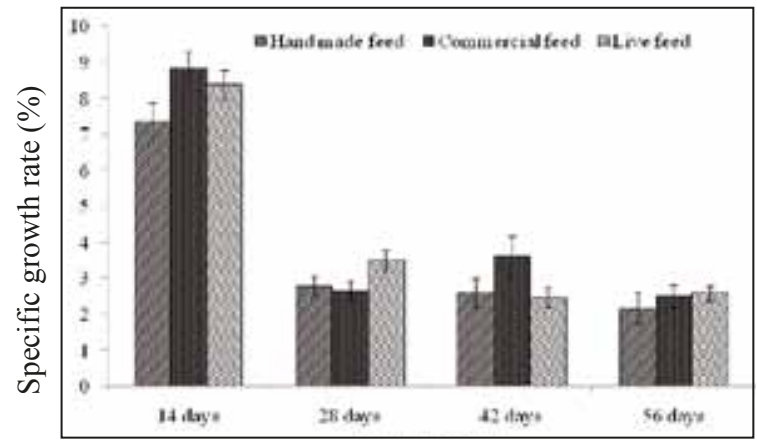

Duration (days)

Fig. 5. Specific growth rate (\%) of Tilapia fry at 56 days rearing period. Bars (Mean $\pm \mathrm{SEM}$ ) with no letters denote no significant difference within group (ANOVA, HSD; p>0.05)

Survival rate (\%): Fig. 6 shows, after culture period of 56 days, the survival rates of Tilapia fry in the handmade, commercial and live feed were $(88.5 \pm 1.5 \%),(91.5 \pm 1.5 \%)$ and $(91.5 \pm 1.5 \%)$, respectively.

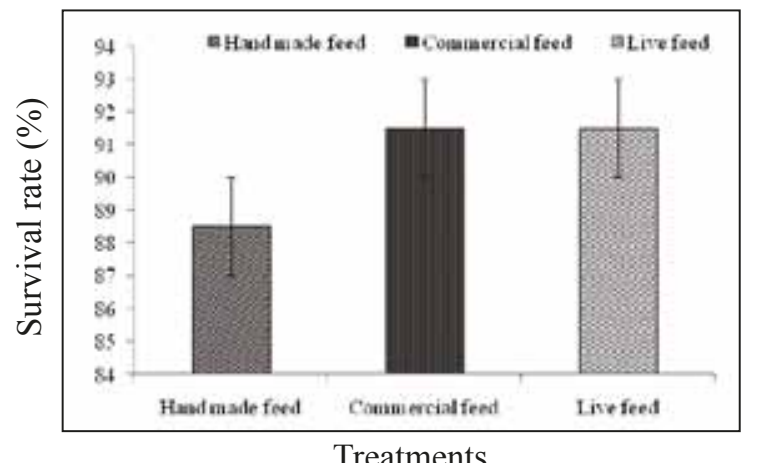

Fig. 6. Survival Rate (\%; Mean \pm SEM) of Tilapia fry at 56 days rearing period. Bars (Mean \pm SEM) with no letters denote no significant difference among treatments (ANOVA, HSD; $\mathbf{p}>\mathbf{0 . 0 5}$ )

In fish, the condition factor $(\mathrm{K})$ reflects the variations on the physiological state in relation to its different factors. Rahman et al. (1997) in a study on the survival and growth of cat fish provided with selected supplemental feeds got the values of condition factor between $0.81-0.87$. On the $56^{\text {th }}$ day of culture of Tilapia fry comparatively higher value $(2.18 \pm 0.09)$ was found in live feed treatment than handmade and commercial feed. From a nutritional point of view, the condition factor indicates the accumulation of fat and gonadal development (Le Cren, 1951).

Watanabe et al. (1990) studied the growth, survival and feed conversion ratio of Florida red Tilapia and found the average daily gain $1.94 \mathrm{~g}$ on 84 days. In this study higher average

daily gain was found in live feed treatment $(0.13 \mathrm{~g} / \mathrm{day})$ than commercial feed $(0.08 \mathrm{~g} /$ day $)$.

For fish fed with well-prepared diets, FCR values below 1 have been reported, although generally it ranges between 1.2 and 1.5 (De Silva and Anderson, 1995). On the $56^{\text {th }}$ day of this study, the estimated optimum FCR was $1.74 \pm 0.17$ when Tilapia fry was fed with live feed. Ogunji and Wirth (2000) proclaimed that FCR was 1.19 when they used fish meal diets and that indicated the most efficient utilization of feed by $O$. niloticus fingerlings.

Fermin (1991) showed that the specific growth rate of sea bass was $18.82 \%$ fed by M. macrocopa. SGR 3.39 at the dietary protein content of $33.32 \% \mathrm{DM}$, indicated the most efficient utilization of feed by $\mathrm{O}$. niloticus fingerlings (average initial weight $4-5$ g) (Ogunji and Wirth, 2000). Average SGR was 3.54 on 84 days was recorded when Watanabe et al. (1990) studied the growth, survival and feed conversion ratio of Florida red Tilapia. In the present study highest specific growth rate of Tilapia fry was found in treatment-3 $(2.58 \pm 0.20 \%)$ fed with $M$. macrocopa. de la Pena (2001) showed that the survival rate of sea bass larvae was $92.4-99.0 \%$ fed by Diaphanosoma celebensis. In the present study the survival rate was $(91.5 \pm 1.5 \%)$ fed by $M$. macrocopa which is very similar.

\section{Chemical analyses of Tilapia fry $O$. niloticus}

Significantly (ANOVA, $\mathrm{F}_{2,3}=32.636, \mathrm{p}<0.05$ ) higher value of moisture was found $(82.76 \%)$ in handmade feed treatment than live feed (78.62\%) (Fig. 7).

Significantly (ANOVA, $\mathrm{F}_{2,3}=50.008, \mathrm{p}<0.05$ ) higher value of protein was observed in live feed treatment $(15.91 \%)$ and lowest value in handmade feed $(10.96 \%)$ at $5 \%$ level of significance.

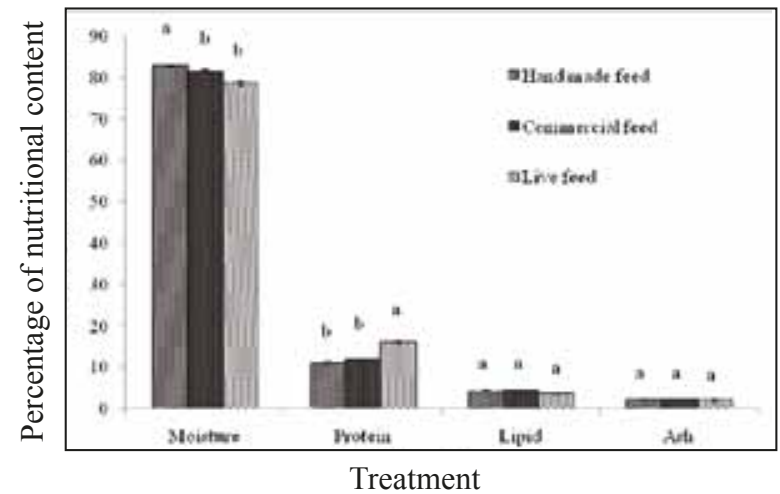

Fig. 7. Chemical composition of Tilapia fry at $\mathbf{5 6}$ days rearing period. Bars (Mean \pm SEM) with different letters are significantly different within groups (ANOVA, HSD; p<0.05) 
For lipid and ash content no significant difference was found among three treatments at $5 \%(\mathrm{p}<0.05)$ significance level.

Concerning chemical composition, crude protein, lipid, fat, moisture and ash contents of Nile Tilapia fed with $M$. macrocopa were better compared to other feeds. However, the highest protein content was observed in live feed. The highest lipid and ash contents were recorded for commercial feed. In a study Desrosier and Derossier (1977) reported that generally fish contain $70-80 \%$ moisture and the amount of protein in fish was reported to be in a range of $13-20 \%$. In another experiment (INFS, 1983) protein content of fresh water fish was reported to be in a range of $15-18 \%$. Govindan (1985) also showed a range of 9-25\% protein in freshwater and marine fish. In the present study, the protein content in treatment-3 is similar to the value reported in these previous studies. Hence, body composition is mainly influenced by the dietary lipid supply and availability as it has been demonstrated in other fish species such as Eurasian perch $(\mathrm{Xu}$ et al., 2001; Mathis et al., 2003). According to Pouomogne et al., (1997) dietary mineral composition influenced crude ash incorporation in body tissues of Tilapia.

\section{Conclusion}

In the present study, significantly positive effect was found by using $M$. macrocopa as live zooplankton feed on the growth and body composition of Tilapia fry. On the other hand, Nile Tilapia fed with handmade feed showed the poorest growth and body compositions. The average daily gain, specific growth rate, survival rate and protein contents were better in live feed treatment of Tilapia culture than those of other treatments. Therefore, M. macrocopa can be used as alternative of commercial feed for Tilapia fry rearing in hatchery and nursery.

\section{Acknowledgments}

We are grateful to Shotota Matshya Hatchery, Mymensingh, Bangladesh for their cooperation during fish fingerlings collection and transportation to the laboratory.

\section{References}

Alam MJ, Ang KJ and Cheah SH (1993), Use of Moina micrura (Kurz) as an Artemia substitute in the production of Macrobrachium rosenbergii (de Man) post-larvae, Aquaculture 109: 337-349.

AOAC (1995), Official Methods of Analysis of AOAC International, $16^{\text {th }}$ Ed., Association of Official Analytical Chemists, Washington DC, USA.

Barriga-Sosa IDLA, Jimenez-Badillo MDL, Ibanez AL and Arredondo-Figueroa JL (2004), Variability of
Tilapia (Oreochromis spp.) introduced in Mexico: Morphometric, meristic and genetic characters, $J$ Appl Ichthyol 20: 7-14.

Benider A, Tifnouti A and Pourriot R (1998), Parthenogenetic reproduction of Moina macrocopa (Straus 1820) (Crustacea: Cladocera): trophic conditions, population density, grouping and temperature influence, Int J Lim., 34: 387-399.

Brooks JL (1959), Cladocera In: Freshwater biology, Ed. Edmondson WT, Wiley, NY, pp 587-656 .

de la Pena MR (2001), Use of juvenile instar Diaphanosoma celebensis (Stingelin) in hatchery rearing of Asian sea bass Lates calcarifer (Bloch), Isr J Aquacult 53: 128-138.

De Silva SS and Anderson TA (1995), Fish nutrition in aquaculture, Chapman and Hall, London, p 320.

Desrosier NW and Derossier N (1977), Elements of food technology, The Avi Publishing Company Inc., p 772.

Fermin AC (1991), Freshwater cladoceran Moina macrocopa (Strauss) as an alternative live food for rearing sea bass Lates calcarifer (Bloch) fry, J Appl Ichthyol 7: 8-14.

Govindan TK (1985), Fish processing technology. Oxford and IBH Publishing Co. Pvt. Ltd, New Delhi, India, p 252 .

He ZH, Qin JG, Wang Y, Jiang H and Wen Z (2001), Biology of Moina mongolica (Moinidae, Cladocera) and perspective as live food for marine fish larvae: review, Hydrobiologia 457: 25-37.

Hutchinson GE (1967), A Treatise on Limnology. In: Introduction to Lake Biology and the Limnoplankton, John Wiley \& Sons, New York, Vol. 2, p 1115.

INFS (1983), Nutrition Survey of Rural Bangladesh, 1981-82, Institute of Nutrition and Food Science, University of Dhaka, Bangladesh.

Jana BB and Chakrabarti R (1993), Life table responses of zooplankton (Moina micrura Kurz and Daphnia carinata King) to manure application in a culture system, Aquaculture 117: 273-285. 
Kang CK, Park HY, Kim MC and Lee WJ (2006), Use of marine yeasts as an available diet for mass cultures of Moina macrocopa, Aquac Res. 37: 1227-1237.

Kenneth MM (1990), Ecology and role of zooplankton in the fishery of Lake Naivasha, Hydrobiologia 208: 131-140.

Khadka RB and Rao TR (1986), Prey size selection by common carp (Cyprinus carpio var. communis) larvae in relation to age and prey density, Aquaculture 54: 89-96.

Le Cren, ED (1951), The length-weight relationship and seasonal cycle in gonad weight and condition in the perch Perca fluviatilis, J Anim Ecol. 20: 201-219.

Loh JY, How CW, Hii YS, Khoo G and Ong HKA (2009), Fish faeces as a potential food source for cultivating the water flea, Moina macrocopa, J Sci Technol Tropics 5: 5-10.

Mathis N, Cyril F and Brun-Bellut J (2003), Influence of protein/energy ratio on carcass quality during the growth period of Eurasian perch (Perca fluviatilis), Aquaculture 214: 453-464.

Ogunji JO and Wirth M (2000), Effect of dietary protein content on growth, food conversion and body composition of Oreochromis niloticus fingerlings, fed fish meal diet, J Aqua Trop. 15: 381-389.

Olojo EAA, Olurin KB and Osikoya OJ (2003), Food and feeding habits of Synodontis nigrita from the Osun River, South West Nigeria, Naga: Worldfish Center Quarterly 26: 21-24.

Ovie SI (1991), Inter- and intra-specific zooplankton predation: some evidence from field analysis of the zooplankton community of Round Valley Reservoir Hunterdon County and Jersey U.S.A., J Aquat Sci. 6: $39-43$.

Pennak RW (1989), Freshwater Invertebrates of the United States: Protozoa to Mollusca, $3^{\text {rd }}$ Ed., John Wiley \& Sons Inc., New York, p 656.

Pouomogne V, Takam G and Pouemegne JB (1997), A preliminary evaluation of cacao husks in practical diets for juvenile Nile Tilapia (Oreochromis niloticus), Aquaculture 156: 211-219.
Rahman MA, Bhadra A, Begum N and Hussain MG (1997), Effects of some selective supplemental feeds on the survival and growth of catfish (Clarias batrachus Lin.) fry, Bangladesh J Fish Res. 1: 55-58.

Rottmann RW, Graves SJ, Watson C and Yanong RPE (2003), Culture techniques of Moina: The ideal Daphnia for feeding freshwater fish fry, Florida Cooperative Extension Service, Institute of Food and Agricultural Sciences, University of Florida, pp $1-9$.

Watanabe T and Kiron V (1994), Prospects in larval fish dietetics, Aquaculture 124: 223-251.

Watanabe WO, Clark JH, Dunham J, Wicklund RI and Olla BL (1990), Culture of Florida red Tilapia in marine cages: the effect of stocking density and dietary protein on growth, Aquaculture 90: 123-134

Xu XL, Fontaine P, Melard C and Kestemont P (2001), Effects of dietary fat levels on growth, feed efficiency and biochemical compositions of Eurasian perch Perca fluviatilis, Aquacult Int. 9: 437-449.

Received: 3 October 2016; Revised: 14 November 2016; Accepted: 28 December 2016. 